\title{
Upaya Penanggulangan Kasus Perdagangan dan Penyelundupan Manusia Sebagai Kejahatan Transnasional Terorganisir
}

\author{
Evi Masrifatin Silvia \\ Fakultas Hukum Universitas Trunojoyo \\ Evimasrifatinsilvia@gmail.com
}

\begin{abstract}
Abstrak
Perkembangan ilmu pengetahuan, teknologi, hingga transportasi telah memudahkan aktivitas dalam segala hal termasuk menghubungkan antar negara di dunia dan membuat jarak semakin mudah dijangkau. Perkembangan ini terjadi pula terhadap perkembangan terhadap kejahatan transnasional terorganisir. Jurnal ini menawarkan penelitian tentang kejahatan transnasional terorganisir berupa perdagangan dan penyelundupan Manusia dengan menggunakan metode penelitian deskriptif kualitatif yang bertujuan untuk mengetahui kejahatan perdagangan dan penyelundupan Manusia merupakan bagian dari kejahatan yang serius. Dengan didasarkan pada sumber data primer dan sekunder. Kejahatan tersebut diatur dalam Konvensi Internasional Tentang Melawan Kejahatan Transnasional Terorganisir (United Nations Convention Against Transnational Organized Crime) beserta protokolnya yang dibentuk oleh Perserikatan BangsaBangsa. Penanganan secara efektif dilakukan antar negara dengan membentuk perjanjian penyerahan pelaku kejahatan transnasional terorganisir berbentuk Perjanjian Ekstradisi atau Mutual Legal Assistance serta memperkuat penegakan aparat antar negara untuk menyelidiki dan melakukan penangkapan terhadap pelaku kejahatan. Perlu kewaspadaan terhadap jenis kejahatan transnasional terorganisir berupa perdagangan dan penyelundupan Manusia dengan metode dan dengan tujuan apapun.
\end{abstract}

Kata Kunci : Kejahatan Transnasional Terorganisir, Konvensi Internasional

Abstract

The development of science, technology, and transportation have made distance more accessible. This journal offers studies on the problem of trafficking and the smuggling of people by using descriptive qualitative research methods. It aims to find out transnational organized crime as a serious crime. It's regulated in the International Convention Against Transnational Organized and its protocol established by the United Nations. Effective handling is carried out between countries by forming agreements to hand over transnational organized crime in the form of Extradition Agreement or Mutual Legal Assistance and strengthening the enforcement of international police to arrest perpetrators. Be aware of the crime of trafficking and people smuggling by any method and for any purpose. 
Keywords : Organized Transnational Crime, International Convention.

\section{PENDAHULUAN}

Seiring arus globalisasi yang semakin menguat, banyak isu yang diperbincangkan oleh masyarakat global, mulai dari isu ideologi hingga isu yang merupakan dampak dari globalisasi. Dampak dari globalisasi tentu ada yang positif seperti semakin meluasnya kesempatan dan jaringan yang tidak terbatas hingga ke berbagai wilayah negara. Namun globalisasi juga memiliki sisi negatif, kesempatan dan jaringan tersebut dapat digunakan untuk melakukan hal yang dapat merugikan negara-negara. Seperti kejahatan yang timbul sebagai efek negatif globalisasi biasanya merupakan kejahatan transnasional yang meresahkan.

Berbagai faktor $\begin{array}{r}\text { yang } \\ \text { memunculkan beragam }\end{array}$ jenis
kejahatan transnasional
keinginan individu atau kelompok
untuk memasuki suatu negara tanpa
batas. Perkembangan teknologi
informasi di era globalisasi menjadi

bagian dari adanya kejahatan lintas negara yang teroganisir di kehidupan yang modern ini. Sehingga kejahatan transnasional semakin meluas, bukan hanya antar negara yang berdekatan melainkan dapat melampaui wilayah negara yang lebih jauh.

Istilah 'transnasional' digunakan dalam Konvensi Internasional Tentang Melawan Kejahatan Transnasional Terorganisir (United Nations Convention Against Transnational Organized Crime atau UNTOC). Dalam perkembangan dunia kejahatan transnasional telah lama menjadi sebuah ancaman yang cukup serius dalam keamanan dan kesejahteraan masyarakat internasional, di lain itu kejahatan transnasional terorganisir menjadi bisnis yang sangat menguntungkan.

Berbagai penyimpangan
yang termasuk dalam kejahatan
transnasional, seperti eksploitasi
sumber daya alam maupun sumber
daya manusia yang berdampak
kepada kelangsungan makhluk
hidup. Dampak dari kejahatan


transnasional pun beragam, seperti kemiskinan dan berbagai konflik sebagai akibat dari kejahatan transnasional, Sifatnya yang dapat melintasi batas wilayah suatu negara memiliki dampak bagi negara lainnya dan menjadikan perbuatan tersebut menjadi berbahaya dan merugikan.

Perserikatan Bangsa-Bangsa (selanjutnya disebut $\mathrm{PBB}$ ) mengadakan pertemuan untuk membentuk sebuah konvensi mengenai Kejahatan Lintas Negara yakni UNTOC atau dikenal dengan Konvensi Palermo pada rapat paripurna yang ke-62 pada tahun 2000 dan diratifikasi oleh negara yang sepakat dengan konvensi tersebut dalam memberantas kejahatan transnasional terorganisir. Dalam konvensi ini terdapat beberapa macam kejahatan yang termasuk ke dalam kejahatan lintas negara, seperti korupsi, pencucian uang, perdagangan flora dan fauna yang dilindungi, kejahatan terhadap benda seni dan budaya, perdagangan dan penyelundupan Manusia secara ilegal serta produksi dan perdagangan gelap senjata api ( $R$. Azizah, 2016 : 2).

Tidak dapat dipungkiri kejahatan transnasional terorganisir yang dampaknya sangat merugikan banyak pihak salah satunya adalah perdagangan dan penyelundupan manusia seiring meningkatnya arus migrasi antar negara sebagai faktor kegiatan tersebut. Perdagangan dan penyelundupan manusia yang sering terjadi meliputi beberapa kegiatan seperti perekrutan, penampungan, pengangkutan, pemindahan, atau penerimaan seseorang dengan menggunakan ancaman hingga penggunaan kekerasan atau bentukbentuk paksaan lainnya. Para pelaku kejahatan memiliki berbagai cara dalam melakukan aksinya, mereka biasanya melakukan kegiatan seperti penipuan terhadap korban, pemalasuan identitas hingga dokumen, penculikan dan penyekapan, hingga melakukan penyalahgunaan jabatan bahkan melakukan konspirasi dengan para pejabat di beberapa negara. Selain itu kejahatan transnasional terorganisir memiliki tujuan yang lain seperti 
eksploitasi seksual dan perbudakan yang biasa terjadi kepada wanita dan anak-anak di bawah umur.

Perdagangan manusia merupakan salah satu kejahatan yang dilakukan antar negara dan cukup sulit untuk diberantas dan dianggap sebagai perbudakan di masa kini dan merupakan pelanggaran hak asasi Manusia (Mochtar Kusumaatmadja, 2003 : 14). Kita tahu bahwa konsep dasar dari kegiatan perdagangan manusia adalah penipuan dan pemalsuan identitas oleh pelaku dan dilanjutkan oleh aksinya berupa perekrutan paksa kepada calon korban yang masuk ke dalam perangkapnya. Kegiatan tersebut memiliki tujuan yang beragam, bukan hanya ekploitasi untuk dijadikan pekerja tanpa mendapatkan imbalan juga menjadi pekerja seksual atau budak dengan menggunakan cara-cara yang telah disebutkan di awal. Hal tersebut tidaklah lepas dari kegiatan lain yang menjadi pendukung atau konsumen yang dapat melakukan penyalahgunaan kekuasaan serta memanfaatkan jabatan tertentu demi menjaga lingkaran kegiatan tersebut tetap berjalan.

Dengan adanya kejahatan yang bersifat melewati batas kedaulatan negara, perlu adanya penanganan yang efektif dengan melakukan suatu hubungan atau membentuk sebuah perjanjian yang dilakukan oleh antar negara. Untuk mengatasi kejahatan lintas batas negara tersebut, maka setiap satuan interpol di berbagai negara perlu melakukan hubungan dengan interpol dari negara lain untuk melakukan penangkapan ke seluruh negara agar pelaku dapat diadili.

Tujuan peneliti memilih topik ini adalah begitu maraknya kejahatan yang bersifat lintas negara seiring perkembangannya yang perlahan meluas. Bagaimana upaya untuk memerangi kejahatan ini yang telah tersebar hampir di seluruh dunia dengan metode sembunyisembunyi sehingga menyulitkan aparat penegak hukum dalam menyelidiki keberadaan mereka. Oleh karena itu peneliti menulis jurnal ini diharapkan dapat memberikan pengetahuan mengenai 
kejahatan yang termasuk salah satu sebagai kejahatan transnasional terorganisir.

\section{METODE PENELITIAN}

Penelitian ini menggunakan metode penelitian deskriptif dengan mengunakan pendekatan kualitatif. Menurut Sugiono, penelitian kualitatif menjadi instrumen kunci dan teknik pengumpulan data dilakukan dengan cara menggabungkan analisis data yang bersidat induktif (MA. Furqon, 2013 : 1). Penelitian ini menghasilkan dan mengolah data yang dilakukan setelah melakukan wawancara dan observasi atau melakukan pengamatan langsung pada indidu yang berhubungan dengan ManusiaManusia tersebut untuk mendapatkan data yang sedang diteliti. Selain itu dalam penelitian ini menggunakan pendekatan historis, ini menunjukkan bahwa perdagangan dan penyelundupan Manusia memiliki variasi yang cukup besar di berbagai wilayah di dunia (Louise Shelley, 2010 : 99).
Penelitian ini ditujukan

untuk mendeskripsikan dan menggambarkan fenomenafenomena yang ada, baik bersifat alamiah ataupun rekayasa manusia, yang lebih memperhatikan mengenai karakteristik, kualitas, keterkaitan antar kegiatan. Penggambaran didasarkan pada kasus-kasus yang terjadi selama beberapa tahun terakhir di Asia, Amerika, Afrika, Eropa dan negara-negara lannya.

$$
\text { Perdagangan dan }
$$

penyelundupan Manusia akan terus berkembang di abad ke-21 yang mana sebagai akibat dari ketidaksetaraan ekonomi dan demografi di dunia, munculnya konflik dan kemungkinan perubahan iklim. Upaya yang terkoordinasi dari pemerintah, masyarakat sipil, komunitas bisnis, organisasi multilateral dan media yang diperlukan untuk membendung pertumbuhannya. Sumber data penelitian ini adalah buku, jurnal, esai, skripsi, dan lain-lain yang membahas mengenai kejahatan transnasional. 
HASIL DAN PEMBAHASAN

\section{Perdagangan Dan Penyelundupan}

Manusia Sebagai Kejahatan

\section{Transnasional Terorganisir}

Salah satu pelanggaran Hak

Asasi Manusia adalah perdagangan dan penyelundupan manusia secara tidak resmi yang masih dilakukan oleh para pelaku di beberapa negara dengan tujuan ke berbagai negara pula. Dikatakan pelanggaran hak asasi manusia karena para pelaku merampas hak Manusia untuk mendapatkan hidup dalam kebebasan dan sejahtera. Tidak hanya itu perdagangan Manusia ini layaknya barang yang dapat diperdagangkan dan tentu saja melanggar hak Manusia.

Pelanggaran berat hak asasi manusia di setiap tahunnya, ribuan pria, wanita, bahkan anak-anak jatuh ke tangan para pedagang manusia di negara mereka sendiri atau luar negeri. Hampir setiap negara dipegaruhi oleh perdagangan manusia, baik sebagai negara asal,transit, atau tujuan tertentu bagi para korban. Pengertian dari perdagang Manusia tidak didefinisikan secara luas, namun kegiatan tersebut disebutkan dalam UNODC terdiri dari perekrutan, pengangkutan, pemindahan, penyekapan, dan penerimaan Manusia. Untuk melakukan kegiatan tersebut para pelaku dapat melakukan segala cara, seperti mengancam atau penggunaan kekerasan, penculikan, penipuan, penyalahgunaan kekuasaan atau jabatan, hingga memberikan bayaran atau maksud tertentu. Dari penjabaran di atas dapat penulis simpulkan bahwa perdagangan manusia merupakan proses menjebak korban dengan menggunakan kekerasan, penipuan, atau pemaksaan dan mengeksploitasi mereka untuk keuntungan finansial atau pribadi.

Pengaruh dari perang dingin dan krisis ekonomi menjadi faktor meningkatnya angka kejahatan ini dan akan semakin memberikan pengarus jika intervensi dalam penyelesaian tidak berhasil. Pentingnya komunitas internasional membuat masalah ini menjadi pioritas yang lebih tinggi di tingkat 
kesenjangan sistematik, yang

satu tantangan terbesar dalam jangkauannya sangat jauh dalam mengembangkan respon permintaan dan pasar konsumen, dan keuntungan dari bisnis perdagangan yang berkembang.

Dalam proses perdagangan terkadang si korban sering mendapat perlakuan buruk yang sangat merugikan saat berada di tempat tujuan, sedangkan pada ManusiaManusia yang diselundupkan hanya datang ke tempat tujuan secara cuma-cuma. Pedagang ini seringkali melakukan trik-trik untuk mendapat korbannya dari yang sederhana hingga berbahaya seperti merayu, menipu, mengancam, mengintimidasi, menggunakan obatobatan terlarang hingga menculik korban. Perdagangan Manusia bisa berkelompok yang terstruktur, dan kebanyakan struktur itu berbentuk piramida sehingga para traffickers dapat melakukan aksinya lewat jaringannya (Louise Shelley, 2010 : 84).

Kejahatan perdagangan manusia sangat kompleks dan dinamis, terjadi dalam berbagai konteks dan sulit dideteksi. Salah penanggulangan perdagangan yang ditargetkan dan mengukur dampaknya adalah kurangnya data yang dapat diandalkan dan berkualitas tinggi terkait dengan skala perdagangan manusia dan profil para korban.

Melansir dari Portal Data Migrasi yang beroperasi di Jerman korban dari perdagangan Manusia tidak memandang jenis kelamin bisa jadi laki-laki, perempuan transgender, bahkan anak-anak yang masih di bawah umur; dari setiap kelompok etnis atau kebangsaan; dan dari berbagai pendapatan atau tingkat pendidikan. Apa yang dimaksud sebenarnya dari kegiatan perdagangan Manusia adalah para wanita atau gadis-gadis yang dikumpulkan dan dieksploitasi seksual atau direkrut untuk bekerja di rumah-rumah pribadi dan terjebak tanpa ada jalan keluar; sedangkan para pria yang tertipu untuk mendapatkan tawaran pekerjaan yang berisiko dan terjebak dalam kerja paksa di suatu bangunan, 
pertanian, atau pabrik. Manusia yang diperdagangkan ini akan dieksploitasi dalam bentuk apapun, termasuk dipaksa menjadi eksploitas seksual, tenaga kerja, pengemis, kejahatan lain seperti menumbuhkan ganja atau melakukan jual beli narkoba, perbudakan rumah tangga,perkawinan atau pemindahan organ.

\section{Menurut}

Harkristuti

Harkriswono, bentuk perdagangan Manusia seperti: pengiriman tenaga kerja ke negara lain dengan menggunakan dokumen yang dipalsukan; menempatkan para korban atau tenaga kerja untuk dieksploitasi menjadi pekerja seksual; melakukan pernikahan yang berbatas waktu yang mendapatkan jaminan finansial; pengiriman calon pengantin palsu; mengadopi anak tanpa proses pengangkatan anak yang sah; serta menculik paksa anakanak di bawah umur untuk bekerja dengan upah sedikit.

Beberapa konvensi internasional yang dibentuk untuk mengatur tentang perdagangan manusia, di antaranya adalah 1)
Konvensi Internasional Untuk Menghapus Perdagangan Budak Kulit Putih tahun 1921; 2) Konvensi Internasional Untuk Menghapus Perdagangan Perempuan Dan Anak tahun 1921; 3) Konvensi Internasional Untuk Menghapus Perdagangan Perempuan Dewasa tahun 1933; dan 4) Konvensi Tenntang Penghapusan Segala Bentuk Diskriminasi Terhadap Perempuan tahun 1979.

Diharapkan bagi pemerintah di setiap negara untuk mengurangi kasus perdagangan Manusia salah satunya dengan menahan ManusiaManusia yang masuk ke dalam wilayah kedaulatannya dengan melalui kendaraan darat, laut, ataupun udara. Bekerja sama dengan negara transit dan tujuan, menyita dana untuk mendukung program anti perdagangan ilegal, serta memberikan perlindungan kepada para korban dan melawan perdagangan anak.

Secara umum kehadiran seseorang maupun sekelompok Manusia di suatu negara dapat diketahui dalam dua hal. Pertama, 
orang yang datang tersebut tidak memiliki latar belakang yang buruk di negaranya. Kedua, orang yang datang tersebut memiliki latar belakang yang buruk di negara asalnya karena melakukan suatu kejahatan kemudian melakukan pelarian diri ke negara lain. Dalam hal pertama apabila orang tersebut meresahkan warga negara setempat hingga melakukan tindakan yang melanggar hukum, maka terhadap orang tersebut dapat dikenai hukuman dengan menyidangnya di pengadilan di negara dimana ia berada atau mengusirnya (mengembalikan ke negara asal), dengan tindakan tersebut maka persoalan dianggap selesai. Akan tetapi terhadap kehadiran seseManusia yang menjadi buronan dari negara asalnya akan berbeda (Wildan Angkasari, 2014 : 49). Kehadiran Manusia tersebut di negara di mana ia berada saat ini untuk menghindari upaya penangkapan atas dirinya yang melakukan kejahatan di negara asal. Bagi penduduk setempat, pelarian Manusia tersebut ke negara lain dirasa dapat meresahkan keamanan dan merasa kepentingannya dirugikan karena Manusia tersebut belum mendapatkan hukumannya, padahal Manusia tersebut telah melakukan pelanggaran hukum (Adji Samekto, 2009 : 25).

Pada umumnya para pelaku perdagangan dan penyelundupan Manusia tingkat transnasional memiliki berbagai cara dan upaya agar terhindar dari tuntutan hukum di negara asal tempat ia melakukan kejahatan. Dengan menggunakan kecanggihan teknologi yang semakin maju, para pelaku kejahatan dapat melakukan perencanaan dan melakukan suatu kejahatan ke suatu negara tanpa perlu mendatangi negara tersebut seperti kejahatan internet dan terkadang dilakukan secara terorganisir dengan anggotanya jika kejahatan tersebut terbentuk dalam satu kelompok.

Semakin banyaknya alat trasportasi yang mudah diakses, para pelaku dapat bergerak dengan cepat dari satu negara ke negara lainnya dan menyepelekan batas negara untuk melakukan kejahatan. Sebagaimana dalam pembahasan 
sebelumnya mengenai perdagangan dan penyelundupan Manusia yang dilakukan secara terorganisir. Dengan pemalsuan identitas para pelaku dan korban susah didentifikasi keberadaannya karena cara pengangkutan korban dengan melalui media darat maupun laut. Batas negara merupakan batas kedaulatan dan kewenangan suatu negara dan para aparat penegak hukum tidak dapat dengan bebas memasuki wilayah suatu negara atau meminta bantuan negara lain secara langsung karena harus melalui prosedur yang memerlukan waktu selama beberapa hari.

Dfinisi yang terkandung dalam Pasal 3 Protkol Perdagangan Manusia dimaksudkan untuk memberikan konsistensi dan konsesus di seluruh dunia mengenai fenomena perdagangan manusia. Oleh karena itu UNODC dalam Pasal 5 mensyaratkan bahwa tindakan yang diatur dalam Pasal 3 diskriminalisasi dalam undang-undang domestik. Legislasi dalam undang-undang domestik tidak perlu mengikuti bahasa Protokol Perdagangan
Manusia secara tepat, tetapi harus disesuaikan dengan sistem hukum domestik untuk memberikan efek pada konsep-konsep yang terkandung pada Protokol.

Legislasi nasional harus mengadopsi luas perdagangan yang ditentukan dalam Protokol. Definisi legislatif harus dinamin dan fleksibel sehingga dapat memberdayakan kerangka kerja legislatif untuk merespons secara efektif terhadap perdagangan yang terjadi lintas batas dan di dalam suatu negara (bukan hanya lintas batas) apakah berbagai tujuan eksploitatif (buan hanya eksploitasi seksual) menghancurkan anak-anak. wanita, dan pria. Yang mana tindakan tersebut berlangsung dengan atau tanpa keterliatan kelompok kejahatan yang terorganisir.

Untuk mengatasi kejahatan transnasional terorganisir beserta pelanggaran-pelanggaran lainnya yang masih berhubungan UNODC membantu dengan merancang undang-undang dan menciptakan strategi nasional anti-perdagangan manusia yang komprehensif tetapi 
juga membantu dengan sumber daya untuk mengimplementasikannya. Demi mewujudkan keinginan tersebut negara akan menerima bantuan khusus termasuk pengembangan kapasitas dan keahlian lokal, serta alat-alat praktis untuk mendorong kerja sama lintasperbatasan dalam penyelidikan dan penuntutan.

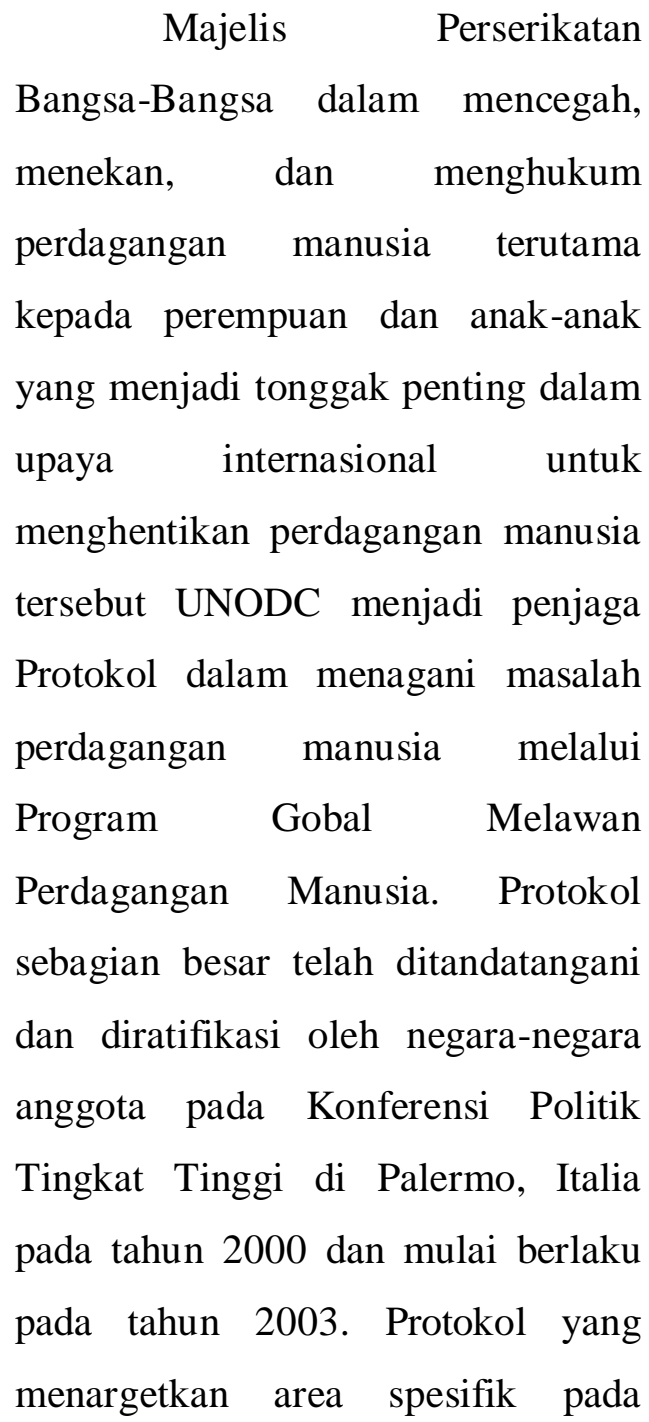

kejahatan terorganisir, diantaranya sebagai berikut: Protokol untuk mencegah, menekan, dan mehukum pelaku yang melakukan perdagangan manusia, terutama pada anak dan perempuan; Protokol menentang penyelundupan imigran gelap melalui darat, laut, dan udara; serta Protokol yang menentang perusahaan gelap dan perdagangan senjata api, bagian-bagiannya dan kompenenkomponennya, serta amunisi.

Protokol ini merupakan langkah besar ke depan dalam perang melawan kejahatan transnasional terorganisir dan menandakan pengakuan oleh negara anggota mengenai keseriusan masalah yang ditimbulkannya, serta kebutuhan untuk mendorong dan meningkatkan kerjasama internasional yang erat untuk mengatasi masalah-masalah tersebut. Negara-negara yang meratifikasi instrumen ini berkomitmen untuk mengambil serangkaian tindakan terhadap kejahatan transnasional terorganisir, termasuk penciptaan kejahatan domestik (partisipasi dalam kelompok kriminal terorganisir, 
pencucian uang, korupsi, dan obstruksi keadilan); adopsi kerangka kerja baru dan luas ekstradisi, bantuan hukum timbal balik, dan kerjasama dalam penegakan hukum; promosi pelatihan dan bantuan teknis untuk membangun atau meningkatkan kapasitas otoritas nasional yang diperlukan.

Bantuan hukum timbal balik (Mutual Legal Assinstance) dalam masalah pidana merupakan permintaan bantuan yang berkenaan dnegan penyidikan, penuntutan, dan pemeriksaan di sidang pengadilan sesuai dengan ketentuan perundangundangan yang diminta ( $\mathrm{T}$. Jessica N. H., 2016 : 3). MLA merupakan perjanjian yang pemberian bantuan yang timbul dalam pergaulan masyarakat dan didasarkan pada hukum formal negara masingmasing. Biasanya dalam pengumpulan dan penyerahan bukti yang dilakukan oleh penegak hukum satu negara kepada penegak negara lain sebagai tanggapan atas permintaan bantuan. Frasa "Timbal balik" hanya menunjukkan fakta bahwa bantuan hukum diberikan dengan harapan akan dibalas dalam keadaan yang sama, meskipun timbal balik tidak selalu merupakan syarat untuk memberian bantuan.

Sejarah pembentukan MLA berawal dari kerja sama antar negara dalam suatu proses saling membantu dalam hal penyidikan masalah pidana yang berawal dari kerjasama antar kepolisian maupun surat yang berisi tentang permintaan bantuanyang didasarkan pada sikap saling menghargai dalam rangka mendapatkan alat bukti yang nantinya akan berkembang menjadi suatu bentuk perjanjian dan berbagai bentuk bantuan lainnya. "Letters rogatory" merupakan suatu surat yang diterbitkan oleh pengadilan negara lain, adanya surat ini dikarenakan prinsip kedaulatan (T. Jessica N. H., 2016 : 3), pengadilan suatu negara untuk menggunakan kekuasaan di luar yurisdiksinya termasuk untuk mendapatkan alat bukti di luar negeri.

Dalam mengajukan surat permintaan bantuan hukum, surat berisi daftar pertanyaan atau tindakan yang akan dilakukan oleh negara 
yang mengajukan permintaan ke negara lain dalam mendapatkan bukti untuk melakukan penuntutan dan perintah pembekuan aset, kemudian dikirimkan ke institusi yang berwenang di negara tempat di mana diajukannya permintaan.

Untuk memastikan penelusuran, pembekuan, penyitaan, penyitaan, dan pengembalian aset secara efektif harus dilakukan dari perjanjian dan konvensi yang tersedia sebagai dasar dalam pemberian bantuan hukum timbal balik. Untuk tujuan ini, negaranegara harus didorong untuk mendaftar untuk perjanjian bantuan bersama internasional dan/atau untuk menegosiasikan perjanjian multi atau bilateral.

Bentuk kerjasama ini muncul dalam praktik pemberantasan kejahatan yang bersifat transnasioanl maupun internaioanl yang dilakukan oleh negara-negara yang terlibat di dalamnya. Sejarah dalam pembentukan kerjasama dalam bentuk ini sangat panjang di dalam praktiknya. Kerjasama yang diawali dengan perjanjian yang dilakukan oleh Pemerintah Amerika Serikat dengan Pemerintah Swiss yang dilakukan sejak tahun 1972, perundingan dilakukan oleh perwakilan dari kedua negara tersebut dan serta berlaku efektif pada tahun 1977.

Berbagai jenis bentuk kerjasama, baik bersifat multilateral maupun bilateral sebagai perjanjian yang dapat dipercaya dalam usaha koordinasi internasional dalam memberantas kejahatan yang telah disepakati sebagai salah satu cara yang dipercaya dalam internationallity coordinated efforts to combat international crimes. Ada banyak bentuk kerjasama internasional yang digunakan seperti bantuan timbal balik yang sudah disepakati di beberapa negara, misalnya yang diatur cukup komperhensif dalam United Nations Convention Against Corruption Tahun 2003 dan United Nations transnational Organized Crime Tahun 2000. Sedangkan pada tingkat regional ASEAN, telah disepakati Treaty Mutual Legal Assistance in Criminal Matters pada tahun 2004. 
Perjanjian-perjanjian tersbut tentu saja berisi mengenai kesepakatan bersama untuk meningkatkan eektifitas otoritas penegak hukum dari para pihak dalam pencegahan, penyelidikan, dan penuntutan pelanggaran melalui kerjasama dan bantuan hukum timbal balik dalam masalah pidana dengan tetap memperhatikan yurisdiksi dari negara pihak. Meskipun dengan adanya perjanjian timbal balik antar negara yang telah disepakati oleh negara pihak, juga diperlukan tindakan lain untuk mendukung kefektifan aturan dan pelaksanaan dari perjanjian tersebut. Selain itu dibutuhkan evaluasi dan monitoring terhadap kejahatan-kejahatan yang telah berhasil ditangani, dengan begitu dapat memperbaharui substansi dari perjanjian agar sejalan dengan perkembangan kejahatan transnasional terorganisir lainnya.

Selain itu penegakan hukum dalam kerjasama internasional seperti perjanjian ekstradisi untuk tujuan penyerahan pelaku kejahatan sedangkan mutual legal assistance untuk tujuan bantuan dalam proses penyelidikan, penuntutan dan pemeriksaan dalam proses persidangan (Noer Hasyim, 2017 : 1 2). Sejak dulu MLAs dilakukan oleh dua negara atau lebih, sebagaimana yang dilakukan di berbagai negara khususnya di antara negara-negara ASEAN. Usaha-usaha masyarakat internasional atau negara-negara dalam mencegah dan memberantas kejahatan transnasional dapat dilakukan dengan kerjasama secara fisik maupun dengan menuangkan pengaturannya dalam konvensikonvensi lama yang sudah berlaku.

Penegakan hukum bagi pelaku kejahatan transnasional sesuai dengan perjanjian kerjasama antar negara, jika mengacu pada asas pacta sun servanda maka pelaku kejahatan transnasional dapat dipidana oleh negara tempat dimana pelaku melakukan kejahatan dalam batas teritorial suatu negara atauatau diserahkan melalui prosedur ekstradisi kepada negara peminta yang memiliki yurisdiksi untuk mengadili pelaku kejahatan tersebut.

Penegakan hukum mengenai kasus human trafficking dengan 
melakukan identifikasi kasussalah satunya adalah perdagangan kasusnya dengan melakukan operasi Manusia dan penyelundupan rahasia atau terbuka, menindaklanjuti Manusia.

petunjuk, dan melakukan pengawasan terhadap si pelaku. Protokol formal yang digunakan untuk mengidentifikasi kasus perdagangan telah digunakan dan sedang dalam proses pengembangan. Untuk melakukan penyelidikan dibutuhkan kehati-hatian karena taktik para pedagang manusia yang digunakan dengan mengancam dan kekerasan terhadap para korban. Para penegak hukum memiliki peran penting dalam pemberantasan perdagangan Manusia.

\title{
SIMPULAN
}

\author{
Kejahatan transnasional \\ merupakan kejahatan yang banyak \\ dilakukan hampir di seluruh negara. \\ Namun kita tidak akan pernah tahu \\ keberadaan mereka karena kelompok \\ mereka atau tempat usaha mereka \\ yang tersembunyi atau yang lebih \\ disebut dengan pasar gelap. \\ Kejahatan transnasional terorganisir \\ yang masih dilakukan hingga saat ini
}


kejahatan tersebut merupakan warga negaranya sendiri.

Kerja sama untuk pemberantasan kejahatan ini disebut Mutual Legal Assistance Treaty yang mana perjanjian ini dibentuk atas dasar Konvensi Internasional Tentang Melawan Kejahatan Transnasional Terorganisir pada Tahun 2000, dan konvensi lainnya yang mengatur tentang kejahatan perdagangan Manusia, perempuan, dan anak.

Kita semua memiliki
tanggung jawab untuk menjaga
anggota keluarga kita aman dan
meningkatkan kesadaran komunitas
kita tentang perdagangan Manusia.
Dalam upaya meningkatkan
kesadaran akan masalah ini, saya
berkomitmen untuk mengenakan
kesadaran perdagangan Manusia
untuk selalu waspada.

Menjelaskan permasalahan ini ke masyarakat tentang perdagangan Manusia dengan segala bentuknya mungkin membantu mereka untuk berpikir dua kali untuk melakukan pekerjaan atau bersosialisasi dengan Manusia lain.

\section{DAFTAR RUJUKAN}

Buku

Kusumaatmaja, Mochtar. (2003), "Pengantar Hukum Internasional", P.T. Alumni, Bandung.

Samekto, Adji. (2009), "Negara dalam Dimensi Hukum Internasional”, PT. Citra Aditya Bakti, Bandung.

Shelley, Louise. (2010), "Human Trafficking: A Global Prespective", Cambridge University Press, George Manson University.

\section{Jurnal}

Angkasari. Wildani, (2014), "Tinjauan Yuridis Perjanjian Ekstradisi Terhadap Kejahatan Ekonomi Dalam Kepentingan Nasional Indonesia”, Universitas 
Trisakti, Jakarta, Lex Nations Convention Against

Jurnalica Volume 11 Nomor Transnational Organied 1, April 2014. Crime (UNTOC) Dan Implementasinya Di

\section{Skripsi}

Azizah. R., (2016), "Efektivitas peran NCB-Interpol Indonesia serta implementasi prosedur ekstradisi berdasarkan Undang-undang RI No.1 Tahun 1979 dalam proses ekstradisi pelaku kejahatan people smuggling Sayed Abbas", Universitas Pasundan Bandung, Bandung.

Hasyim. Noer, (2017), "Pelaksanaan Ekstradisi Antar Negara Dalam Menangani Masalah Human Trafficking Menurut Hukum Internasional”, Universitas Islam Sultan Agung, Semarang.

Hermanto. T. Jessica Novia, (2016), "Mekanisme Mutual Legal Assistance (MLA) Terhadap Penyelesaian Kejahatan Yang Diatur Dalam United
Indonesia”, Universitas Lampung, Bandar Lampung. 